\title{
The Coupling Effects of World-System Position and National Capitals on Relative Economic Growth in Developing Countries
}

\author{
Edward L Kick ${ }^{1 *}$, Thomas R Burns², Laura McKinney ${ }^{3}$ \\ ${ }^{1}$ Department of Agriculture and Resource Economics, North Carolina State University, USA \\ ${ }^{2}$ Department of Sociology, Oklahoma State University, USA \\ ${ }^{3}$ Department of Sociology, Tulane University, USA
}

Submission: September 05, 2017; Published: September 22, 2017

"Corresponding author: Edward L Kick, Department of Agriculture and Resource Economics, North Carolina State University, USA, Email: elkick@ncsu.edu

Abstract

We theorize about and test the effects of the military and education expansion as strategies of economic growth for developing countries, emphasizing these capital effects are conditioned by more global, or world-system processes. Early sociological theory neglects global forces but offers foundational themes that link social capital such as militarization and schooling to economic advance. These themes are refined in more modern treatments. Theory and research in sociology has engaged in sharp contention more recently, particularly on whether global forces have favorable impacts on national capital and economic growth in developing countries, and the degree to which these impacts flow from economiccentered or cultural dynamics.

We use prior theory to build a perspective which argues that different "couplings" of national military and educations processes with the positions of relative power or dependency in the world hierarchy produce variations in national economic growth in the developing world. We use regression results to show, for example, the comparatively favorable economic consequences of semiperipheral position of nations to peripheral location in the system when coupled with capital expansion in education, and with one component of the military capital, the population's participation in the military. Theory and results suggest a need for deeper theorization in the sociology of national development. This should focus on global and national economic and non-economic forces, their couplings with national capitals in the developing world in producing economic growth, and the importance of focusing on semiperipheral and peripheral countries in a non-isomorphic way.

\section{Introduction}

Our theoretical and empirical foci in this study are the linkages of the global economic and cultural dynamic global system to military and educational capitals and the impacts of these linkages on differential economic growth in the poorer countries of the world-the "semiperiphery" and the "periphery." The per capita national income gap between semiperipheral and peripheral countries has continued to widen [1-4] (Foot Note 1). In many poorer countries per capita national income is less than $\$ 1000$ per annum, while income for the most developed or core countries of the world system commonly exceeds $\$ 50,000$. However, general distinctions such as these may distract attention from significant differences in economic well-being among the developing countries themselves. The upper tier or semiperiphery [5] of the global system enjoys approximately a five-fold per capita income advantage over the poorer periphery, but far less theoretical and empirical attention is paid to these differences than to differences between the richest and poorest countries of the system.

Sklair [6] correctly observes that many contemporary issues such as economic growth in poorer countries cannot be satisfactorily examined solely at the level of the nation state. What is needed are theoretical directions and related empirical assessments that adopt a "coupling" approach that ties global dynamics to key national capitals and then ties these couplings to differential economic outcomes across poorer nations. Unfortunately many treatments which adopt this logic focus rather exclusively on economic antecedents to growth [7], but we follow contemporary modernists [8], neo-capitals

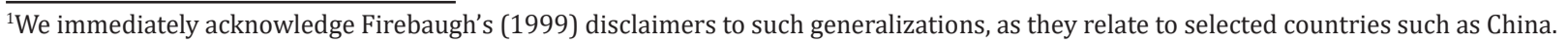


[9], and other global system scholars [10], in arguing that world cultural dynamics and domestic social capitals also are fundamental to economic growth. As preliminary illustrations, consider arguments that the military may serve in nationbuilding, infrastructural progress, and economic and human capital improvements [11-15], and that economic growth can be attributed in part to the human-capital generating role of educational expansion [16-20].

Social capitals, including the educational and military systems that are at the center of our effort, have been at the core of sociological inquiry on societal growth since the discipline's inception nearly two centuries ago. Comte [21] and others viewed a rapidly industrializing Europe and used evolutionary themes to explain what they felt was the inevitable progress of societal capitals and economies from primitive to the most contemporary states, as exemplified by France. Spencer [22] theorized about growth, differentiation, integration and adaptation of societies, while linking rationality, laws and scientific advance to institutional change and economic growth. Durkheim [23] furthered these emphases in his focus on the natural evolution of societies from mechanical to organic solidarity, through capitalsthat induce collective values that support an advancing division of labor and economy. Weber [24] clearly saw an inevitable march toward capital rationality and bureaucracy as they coupled with changes in key societal values, spurring economic growth.

"Modernization" theorists use themes from foundational sociology to further tie societal capitals to economic change in the modern era. For example, they refer to the classical arguments that societies evolve through the differentiation and reintegration of social capitals and related economic growth, and emphasize that Western technology and value systems spur these changes as they alter traditional obstacles to national development [25,26]. Modernization theory also introduces components of westernization and "globalization" to the national development process. Following Weber [24], an important component of the national evolutionary dynamic of developing countries is the individual modernity created by social capitals such as education, which introduce the new, albeit external, values and ideas that grow economies [16,27].

The evolutionary coupling of capitals, economic growth and westernization flowing from modernization approaches is challenged by dependency and world-system perspectives on national development and economic growth. Latin America dependency economists [28] challenge the view that "Westernization" can create substantial evolutionary progress in the capitals and economies of third world societies. Dependency theorists in sociology rely on a neo-Marxian critique in their contention that underdevelopment and economic stagnation in poorer countries is not remedied by Western modernizing forces, but rather reinforced by them. The international division of labor is controlled by rich capitalist countries, and unequal exchanges between them and other countries cause underdevelopment in poorer societies [29]. Cardoso [30], Cardoso \& Faletto [31] and others [32] emphasize that capital penetration by the West into the third world creates social capitals that serve foreign capital and local elites, leading to economic stagnation and not growth for dependent societies.

Coupling arguments in more recent global approaches reach further back in time to address the onset of the modern world system $[5,10]$, while expanding dependency and modernization approaches, to address a global division of labor and a world political and cultural system that shape national capitals and economic outcomes throughout the globe. World-system theory [5] identifies a "core" of wealthy and powerful capitalist countries with linked states and multinational corporations operating in tandem in an international division of labor that supports the relative capital and economic progress of the core. This advantage comes at the expense of a "periphery" that becomes "disarticulated" institutionally and economically due to these exploitive global exchange relationships [33]. "Semiperipheral" or "advanced peripheral" countries [34] benefit relative to the periphery from these global arrangements because they exploit the periphery as well in their economic exchanges with them, although the same type of arrangements cause them to fall further behind the core.

The coupling of the global system to national institutional and economic outcomes is viewed primarily in economic terms by most world-system theorists [5], but in recent decades global system analysts questioned the singularity of this focus and adopt non-economic focal points as well $[6,10,35,36]$. Institutional theorists in particular, such as Meyer [10,37] and Boli \& Thomas [38], demonstrate that a Westernized global culture increasingly fashions national capitals well beyond the impacts of local circumstances. Thus, Ramirez \& Boli [39] show that global diffusion of educational forms is linked to a range of economic outcomes. In a number of ways then, they globalize Weber's foundational argument about the important roles culture and capitals play in generating economic advances [24]. Thus, domestic capitals differentially affect economic growth among developing countries, as they couple with international networks of power and dependency reflected in nations' semiperipheral or peripheral status in the world-system $[4,15,40]$.

The model of economic growth we develop treats economic and non-economic, as well as national and international factors together, emphasizing the impact of "coupling" dynamics among them as the key to economic outcome differences between semiperipheral and peripheral countries. We begin with a theoretical overview of relevant global-system arguments.

\section{Theoretical Arguments}

\section{Overview of global-system arguments}

As is true for all social systems [41-45], the global system is governed by the structure and process of exchanges among its constituent units. The global-system units we focus upon theoretically and empirically are nation-states, though 
multinational corporations ad global cities [46] are central to the operation of the modern world economy. Indeed, recent treatments emphasize a modern period of "epochal shift" centered on transnational corporations, a transnational capitalist class [47], and a cultural ideology of consumerism [6]. However, we agree with Sklair [6] that the ascendancy of globalizing forces is not so powerful that the existence of the nation-state is in serious doubt, and only the most extreme interpretations of globalization view this as an inevitable consequence [6]. Nation-states remain the most critical actors in the global system as a whole while being especially important as causal agents producing national outcomes such as economic growth [48] (Foot Note 2).

Many world-system and dependency theorists emphasize that for centuries, power and dependency relationships have congealed to structure a global stratification system formed of constituent nation-states (e.g., "core," "semiperiphery," "periphery" - Wallerstein [5]; Chirot [49]). The position of great global power enjoyed by the core, relative to the semiperiphery and periphery in the world system [5], stems in an important way from the transfer of value produced in these other regions to the core (Friedmann [48]: 306-307). In lesser degree this holds as well for the semiperiphery, which appropriates value from the periphery. There are disagreements among world-system and dependency theorists over the precise nature of this value transfer, including the critical importance of level-of-processing distinctions, capital versus labor-intensive production differences [50], or high-return economic activity as a totality, regardless of its origin [51]. For our present purposes we adopt the latter emphasis and focus upon those constellations of economic and non-economic activities that, taken as a whole, create a global hierarchy [35,36].

In fact, while the determining role of global economic forces in the world economy often is generally conceded, we emphasize as well the fundamental role in the world system played by cultural processes $[10,35,39]$ and political-military dynamics [35,36,52-54]. The role of non-economic forces in globalization is increasingly acknowledged across global cultural or societal approaches [6]. There is deep interpenetration among economic, political, military and cultural forms of international linkages, inasmuch as each reinforces and in many ways determines the others [55]. In addition, each relationship type in the system can be viewed as encompassing some fundamental exchanges based on dimensions of power and dependency, whether those are, for example, trades of technology for raw materials, or trades of armaments for political-military concessions.

As is true in all exchange networks, what is crucial in the global system is the ability of some units to effectively resist the control of others, while promoting or enforcing a "logic" of exchanges on the system, a logic that benefits them relative to others. Those benefits for nation-states include the maintenance of global power and the close coupling of their international power to domestic capitals, so as to produce favorable national outcomes such as economic growth. The powerful nation-states of the core have maximal ability to meld extranational and intranational forces to reach favorable domestic economic outcomes. Their national development strategies are least constrained by other network actors, and their "articulated" economics and capitals foster best the constellation of human capital, rationalized production and complex division of labor that generate domestic economic growth [56-58]. These articulations serve as the point of theoretical departure for this study, and we begin with a summative review of economic articulation and disarticulation, and the role of the latter in limiting growth in dependent nations in the world economy.

\section{Global system, economic articulation and economic growth}

Much has been written already on the role of economic disarticulation and its negative consequences outside the core of the world system. As a necessary preliminary, however, it is important to highlight some generic processes in this dynamic. For example, Breedlove \& Armer [58] build on prior work from dependency theory $[56,57]$ to provide specifics on how the economic (dis)articulation process is likely to operate in an ideal-typical sense. They argue that in developed nations, as capital accumulates, it tends to stimulate the overall economy because of two key factors: rising wages and a domino-effect of "forward" and "backward" [59] economic linkages. This latter aspect is characteristic of what economists working in a complexity-theory paradigm (in contrast to the neo-classical idea of the law of diminishing returns) refer to as the principal of increasing returns [60-62].

The two factors work together to foster an "articulated" economy that further magnifies growth. A rise in wages in turn tends to stimulate added economic growth because of the increased purchasing power of workers and the demand for new goods that it creates. Further, in an articulated economy each of the areas of the economy are linked to one another; thus, demand for goods creates demand in other areas of the economy related to the production of those goods. The opposite is true for nations on the periphery of the system. Global-system logic imposes significant constraints on the periphery, as have the historical workings of the world system and other long-term geographical disadvantages [63]. Much of the periphery is characterized by dual and "disarticulated" economies, based on a mal-integrated urban and "outward-looking" export-oriented sector of the economy that is comparatively isolated from agrarian sectors $[56,57,64]$.

Despite crucial differences these arguments are in many ways consistent with fairly straightforward and longstanding

${ }^{2}$ The conjunction of the nation and state is taken as fundamental by world-system theorists in particular, because states are nodes in international networks and they act on behalf of major economic actors such as multinational corporations. 
theory in the economic growth literature [27]. Compared with the periphery, semiperipheral countries have a much higher percentage of the labor force engaged in services and manufacturing than in agricultural production for domestic consumption [3]. The export structure of the semiperiphery more typically is based on a balance of high-demand minerals and agricultural goods, often oil, and frequently processed goods, such as textiles. Since articulation of the economy and concomitants such as a more complex division of labor, rationalized production, and human capital development are greater in the semiperiphery, so too are the corresponding payoffs to investments.

These dynamics point to different economic growth outcomes for the semiperiphery and periphery due to the couplings of global position and domestic economy. Processes that mirror and reinforce these also are visible in the couplings of the world system to domestic social capitals. Many traditional arguments assume that a given social capital serves a relatively circumscribed and monolithic function across societies and that social capitals are themselves mutually reinforcing [25]. Schooling, for example, is assumed to be a primary and near universal developer of human capital such as those social and technical competencies that foster economic advance. However, we emphasize that the functional impact of a given social capital may differ depending not only on the operation of other national capitals but also on the more macroscopic structural arrangements in which it is embedded (i.e., the global system).

\section{National capitals and economic growth}

We are theoretically and empirically interested in the connections between economic growth and components of two types of educational and military capitals as they are coupled to the global-system domain. We note at the onset of our arguments that there has been a significant movement in sociology and the social sciences generally to examine the role of social capitals in stimulating national economic growth $[8,9]$. Sachs [63] and North [65] argue persuasively that neoclassical economic theory cannot provide a sufficient explanation for economic growth, because it neglects the vital role played by social capitals (Foot Note 3).

Classical sociological interpretations $[23,24]$ and the more recent work of "modernization" theorists (e.g., [25,66,67,16,27] Parsons [25]; Levy [66]; McClelland [67]; Inkeles \& Smith [16]; Rostow [27] set the foundation for neo- capital work in sociology $[8,68]$. At the risk of oversimplification we note that Durkheim's [23] approach to the evolution of societies emphasized the movement from simple and undifferentiated forms to more complex types, as infrastructural changes such as improvements in transportation and communication lead to an increased competition for existence and a broadened societal division of labor. Weber identified the importance of religion and the military in rationalizing everyday life and integrating those cultural values such as discipline that spur entrepreneurial behaviors and capitalism [24]. Related modernization themes similarly focus upon the crucial role of social capitals and values in supporting societal complexity, efficient production and economic expansion [25,66] (Foot Note 4).

Some contemporary capitalists [8] extend themes in classical sociology to interpret the modern roles capitals and culture play in promoting national development and economic growth. Neocapitalists explore the impact of "cultural values" on economic growth, as they consider "capitalist" capitals [63], productive versus "unproductive" cultural norms [69], (non)competitive mindsets [70], enduring cultural traditions [71], and "antieconomic" values [72].

Another important component of our argument rests on the variability in capital performance across the world system. Just as a number of new capitalists focus on the prodevelopment forces of capital and cultural modernization, others more closely follow sociology's historical concern over the less favorable results of capital and societal change. Some capitalists emphasize that underlying and traditional normative structures restrict the field of acceptable capital changes, which are filtered as well through comparably constrained formal capital [68]. Societal and interorganizational "density" as well as a nationally shared "discursive" also are consequential in translating institutional content into economic advance [73-75]. When taken together classical and contemporary treatments generally link social capital and capital-inspired values to cross-societal differences in economic expansion, although the linkages often drawn are not contextualized based on global dynamics. These arguments serve as part of the backdrop for our consideration of the role of national military and educational capitals in promoting relative economic growth in the semiperiphery and periphery.

\section{Theorization on the military and economic growth}

The military capitals represents the largest single component in most government bureaucracies in developing nation-states. Armed forces in the developed and developing world were at parity in 1970; although, in more recent years the balance has shifted and close to two-thirds of the world's soldiers are in developing countries alone. The over 15 million soldiers in developing countries and their fellow citizens are more likely than not to be the subjects of military-controlled governments. Democracy has spread globally but in over sixty developing countries the military capital exercises significant executive,

${ }^{3}$ The congruence between a system logic and our approach is unmistakable. What may be less transparent is our ultimate goal of applying the logic utilized to a multiplicity of analytical domains and the couplings between them. Our emphases on alternative, but "viable paths" to development are consistent with other recent treatments of cross-national comparative advantage (Biggard and Guillen 1999).

${ }^{4}$ Some social-psychological variants of modernization theory point to an important link between the "need" for individual achievement and societal entrepreneurship and modernization (McClelland 1961). Related treatments in economics (Rostow 1962) stress that when the values favoring economic progress are coupled with national expansion in education and entrepreneurship, the foundation is laid for a "take-off" stage in economic growth. 
judicial and legislative power over the citizenry [2] and the military capital presence is deeply felt in the bulk of Latin America, Africa, the Middle East, and South-east Asia.

Dependency scholars [76] argue with some cogency that "militarization" greatly limits development among non-core countries [77]. Military regimes often are heavily reliant upon core countries for political-military support exchanged for the implementation of patron-conditioned social and economic policies. These policies may contribute to economic stagnation and other social ills $[78,79]$, although the empirical evidence for negative regime effects on economic growth is both contradictory and controversial [80]. It is nonetheless clear that military regimes often deny their populations basic domestic political freedoms just as they create cycles of repression, weapons procurement, mass violence, foreign military intervention, and consequent human welfare stagnation.

The effects of militarized regimes on economic growth are uncertain, but consistent findings have emerged showing that another component of the military capital, military participation, may under certain conditions generate modernizing and prodevelopmental results [13-15,81-84]. Weber argued that a broadened military capital relatedly fosters norms of individual and group discipline that benefit economic growth [24]. Later theoretical work in the sociology of military capitals has identified the benefits of a cohesive and technically skilled military, drawn from a progressive middle class that attempts to overcome traditional obstacles to development while catalyzing modernization $[81,82]$. Military training fosters human capital as well as it heightens basic literacy and numeracy and general and technical educational levels, which in turn create more rationalized and efficient means of production and societal organization $[13,16]$.

But consider too that expansion in military participation requires infrastructural accommodations that in principle have far reaching benefits beyond the military sector $[12,85]$. Military requirements for added domestic transportation and communication networks can complement existing infrastructure, facilitating infrastructural improvements generally, while heightening "moral density" and complexity in the division of labor [23,34]. Modernists and neo-capitalts converge in their arguments that these consequences spur economic growth $[8,14,15,68,86-90]$.

In a decidedly more pragmatic way military personnel may directly foster economic growth through participation in civic programs and domestic production. This dynamic is visible in some Latin American settings where the military periodically assumes a role in the construction of roads, bridges, schools and health facilities in poorer areas. Parallel functions have been demonstrated for a wide range of developing countries in Africa, Asia, and the Middle East, although evidence suggests the military's role in this respect is especially pronounced for non-core nations in the semiperiphery, as compared with the periphery of the world system [89].
Despite the pernicious social consequences associated with repression and the possible economic costs of military dictatorships, armies in and of themselves may benefit some developing countries economically. These economic payoffs to military capitalization are not uniform across the developing world, and payoffs are likely to be the greatest among semiperipheral nations. When compared to the periphery, semiperipheral countries are already less dependent internationally and have a relatively more complex, rationalized and articulated internal division of labor based on expanded human capital. Among peripheral countries a progressive and entrepreneurial middle class is essentially absent. When military capitalization is coupled to dependent economic production in disarticulated economies with weak infrastructures, as is also the case in the periphery, military infrastructure offers little "value added" and relative economic growth is an unlikely companion to a broadening of the armed forces. These arguments anticipate an empirical expectation of favorable effects of the coupling of world-system position and broadened military participation on economic growth for semiperiphery relative to periphery countries.

\section{Theorization on education and development}

A variety of researchers have noted the connection between educational expansion and economic growth in developed settings, even if that connection is by no means isomorphic $[18,19,91]$. For instance, Walters \& Rubinson [20] find a relationship between secondary educational expansion and economic output in recent years in the United States, although the relationship is not uniform for much earlier segments of U.S. history.

One key to interpreting uneven results for developed as well as developing countries again may be found in the coupling between the domestic economy and social capitals supplying stimulants to economic growth. Hage's et al. [19] offer an historical study of the French system which finds that when a "strong and active" state exercises standardization and qualitycontrol over the education system economic productivity is relatively more efficient. When states are weak and the coupling between education and economy is comparatively absent the payoffs to educational expansion become much more tenuous.

Studies of developing countries havelinked theinterventionist policies of strong, especially semiperipheral, states to educational expansion and related economic growth [33,92-95]. In line with neo-capitals theory, Anderson [95] emphasizes more broadly that for modernizing countries education is essential to national development because it promotes socialization, national unification, coordinated administration and the inculcation of occupational and leadership skills [16,39]. Nationbuilding and the inculcation of basic skills happen first with expansion in primary education that has been tied empirically to economic growth in poorer countries, in developing countries overall [96], and in the more highly developed semiperiphery of the world system $[97,98]$. Primary education is the one 


\section{Agricultural Research \& Technology: Open Access Journal}

capital form that can be instrumental in creating a broadened commonality in values and norms and advance those human capital and inter organizational linkages that heighten moral and infrastructural density and promote economic growth. However, our theorization anticipates relative greater payoffs to primary education in the semiperiphery than periphery.

Apart from the more universal and basic content of primary education, the structure and content of education in the periphery is to a significant extent driven extranationally. This arrangement arguably benefits the core as well as peripheral elites and others in the periphery associated with the "modernized" production zones in some urban areas. But the economic payoffs to "educational dependency" are far less certain for the bulk of the population in the disarticulated economies of the periphery [99,100] (Foot Note 5). As Meyer et al. [10] point out: Children who will become agricultural laborers study fractions; villagers in remote regions learn more about chemical reactions...Deeming such practices rationally functional requires a breathtaking leap of faith. Impoverished countries routinely establish universities producing overqualified personnel, national planning agencies writing unrealistic five-year plans, national airlines that require heavy subsidization, and freeways leading nowhere-forms of "development" that are functionally quite irrational.

The more tightly coupled education is with an articulated national economy the greater, in principle, is the payoff in terms of economic growth. This has been demonstrated in the case of developed countries such as France and Germany [18,19], and it appears to be true for developing countries as well. Yet, as is the case for one component of military capitalization, the more profound effects of education on economic progress should be seen in the relatively more complex, articulated, and rationalized economies of the semiperiphery [93,101]. Meyer et al. [10] argue cogently that the more tightly networked a nation is to the worldsystem, the greater the likelihood it will adopt a "definition of progress...rooted in universalistic scientific and professional definitions that have reached a deep level of global." institutions We emphasize in addition that in the developing world countries closer to the center of power in the system are relatively more able than those less central to parlay their coupling of globalsystem power and capitalization expansion into domestic economic growth.
When taken together, our arguments about education and the military emphasize that global power and dependency couple with different components of domestic capitals in developing countries to produce variable outcomes in economic growth. Couplings based on greater global power and national articulation should produce more favorable economic growth outcomes. Couplings based on some types of domestic capitals such as military participation generate comparatively better economic results than others (e.g., military regimes).

\section{Methodology}

\section{Sample}

To test these arguments we report results of cross-national regressions based on data from 59 developing countries listed in Appendix A. Descriptive statistics and correlations are displayed in Appendix B. We employ Kick's [102] worldsystem classification to identify periphery and semiperiphery countries in general as reproduced in Appendix A (for discussion see, among others, [15,103-105], and we follow conventional procedures in omitting cases if data are missing for them on one or more measures (Foot Note 6).

\section{Dependent variable}

Our measure of national economic development is change in per capita gross domestic product over the period of 19701985 [3]. The period chosen reflects a defensible historical stream wedged between the end of the colonial era and a new capitalist world order for which reliable data are available [106]. We recognize as well that per capita gross domestic product change only reflects economic development in a material sense. Theoretical and empirical examinations of a much broader range of development measures such as political rights and health outcomes ultimately are desirable. Existing theory applies principally to economic outcomes and as a consequence we focus on them (Foot Note 7).

It is important to emphasize that the per capita GDP measure (GDPC) used is not a rate measure. Many relevant treatments, including economic studies, rely upon growth measures expressed as rates [107]. Our emphasis on well-being chasms across the world system dictates our choice of a relative emphasis and a measure based on "absolute" per capita GDPC changes. We liken

${ }^{5}$ We recognize that post-colonial relationships impact education in much of the periphery, and that the nature of these relationships sometimes differs, say, between Anglophone and Francophone countries in Africa. A more nuanced approach than ours might trace the economic constraints imposed by specific forms of colonial heritage.

${ }^{6}$ We omit core countries from the analysis because our focus is upon differences in economic growth among developing nations only. Our theoretical presentation is consistent as well with this focus. We also note that there are alternatives to the country classification procedures we employ, for example, Nemeth and Smith (1985), Arrighi and Drangel (1986); and Terlouw (1993). Each of these has strengths and weaknesses. Nemeth and Smith use economic criteria central to world-system theory and provide a sound measure of position in the world economy but they do not consider non-economic networks central to structure and process in the world social system (Galtung 1971; Snyder and Kick 1979; Meyer et al 1997; Boli and Thomas 1997). Arrighi and Drangel consider only characteristics internal to a country, which for present purposes would introduce a tautology into our empirical test. Terlouw considers multiple dimensions and examines factors external to a country, but operates from a limited case base that unduly restricts analyses such as ours. We note that other supranational economic, politico-military, and cultural links that tie organizations to individual nations and to one another are key but unmeasured components in our treatment (see Boli and Thomas 1997: 171-174).

${ }^{7}$ It is clear that "purchasing power parity" data are an alternative to the measure we employ here. These data are especially useful when examining domestic quality of life issues. Insofar as our empirical focus is cross-national differences in wealth in a globally-shared marketplace, we prefer the GDPC measure. We note, however, that our subsequently reported model estimations differed little across these alternative measures. 
rate studies of economic growth to annual assessments of rates of increase (decrease) in a personal bank account or salary. We would like our use of relative growth measures to comparisons of the change in our total bank account or salary relative to others. Rates are important in the long-term study of growth or decline, but they do not encompass the crucial base and growth in that base. Consistent with world-system theory approaches we emphasize that in national economies and personal savings accounts sizeable growth rates on low bases will general in principle lead to far less favorable financial growth that smaller increases on much large bases.

\section{Independent variables}

The regression equations include the initial state of the dependent variable, per capita gross domestic product measured circa 1970, to account for the different developmental "starting points" of the countries in our sample. The data are taken from the World Bank [3].

Our two components of military capitalization are: the military participation ratio or the number of soldiers per 1000 , averaged for the years 1970 through 1984 [108]; and the count of the number of years of military rule during 1970-1984 [109]. In correspondence with our earlier arguments we use two component measures of education: the ratio of the number of students enrolled in secondary school to the number of total possible enrollees for the age group averaged for 1970-84 [3]; and the ratio of the number of students enrolled in primary school to the number of total possible enrollees for the age group averaged for 1970-1984 [3]. Education often is seen as a force of societal integration and human capital formation, but we emphasize the more probable, relative economic growth effects of education in non-core settings.

We estimate the effects of the value of domestic investment per capita averaged over the years 1970-84 [3]. We omit foreign investment $[11,103,110,111]$ because for our sample it is technically redundant with domestic investment. When excluded

Appendix B: Means and Standard Deviations

\begin{tabular}{|c|c|c|}
\hline & Means & Std. Deviation \\
\hline GDPC Difference & 131.439 & 1099.348 \\
\hline GDPC85 & 1052.758 & 1000.688 \\
\hline GDPC70 & 921.32 & 317.84 \\
\hline Domestic Investment & 252.156 & 3.386 \\
\hline Military Participation & 4.049 & 6.973 \\
\hline Military Regime & 8.034 & 26.351 \\
\hline Primary Education & 82.746 & 18.443 \\
\hline Sencondary Education & 30.11 & 1.514 \\
\hline W.S. Education & 7.864 & \\
\hline
\end{tabular}

r Identifies a variable that has been residualized

Appendix C: Correlations from our estimations results for our other regressors essentially remained unchanged.

As a control variable in our regression estimations, we include a modified world-system classification measure that is a six-category ordinal variable [102]. This variable distinguishes the more and less central (i.e., powerful) nations in the world system - those that are respectively more or less closely tied into the global system $[10,38]$. This measure reflects global networks of power based on economic, political, cultural and military dimensions rather than economic linkages only $[35,102,107]$.

To measure the couplings of national position in the global system to the five substantive regressors we construct our multiplicative "coupling" variables using two dummy variables based on this ordinal variable (i.e., coded unity for the "semiperiphery" and zero for the "periphery" and vice-versa) see Appendix A for a listing. Since we theorize that the greatest growth payoffs stem from a coupling of institutional expansion and global power and connectedness, we create a series of variables based on the coupling between position in the system and the aforementioned domestic capitalsvariables.

\section{“Semiperiphery" Countries ( $\mathrm{N}=41)$}

Algeria, Argentina, Bolivia, Chile, Colombia, Costa Rice, Dominican Republic, Ecuador, Egpty, El Salvador, Ghana, Guatemala, Guyana, Honduras, Haiti, Indonesia, India, Jamaica, Kenya, Korea (Republic of), Liberia, Morocco, Mexico, Malaysia, Nigeria, Nicaragua, Pakistan, Panama, Peru, Philippines, Paraguay, Saudi Arabia, South Africa, Sri Lanka, Thailand, Trinidad and Tobago, Tunisia, Turkey, Uruguay, Venezuela, Zaire.

\section{"Periphery" Countries ( $\mathrm{N}=18)$}

Bangladesh, Benin, Burundi, Central Africa Republic, Ethiopia, The Gambia, Madagascar, Malawi, Mali, Mauritania, Niger, Rwanda, Senegal, Sierra Leone, Sudan, Togo, Zambia, Zimbabwe 
Agricultural Research \& Technology: Open Access Journal

\begin{tabular}{|c|c|c|c|c|c|c|c|c|c|}
\hline & $\mathbf{1}$ & $\mathbf{2}$ & $\mathbf{3}$ & $\mathbf{4}$ & $\mathbf{5}$ & $\mathbf{6}$ & $\mathbf{7}$ & $\mathbf{8}$ & $\mathbf{9}$ \\
\hline GDPC difference & 1000 & 0.425 & 0.106 & 0.036 & 0.412 & -0.091 & 0.278 & 0.402 & -0.354 \\
\hline GDPC85 & 0.425 & 1 & 0.945 & 0.979 & 0.4 & -0.249 & 0.342 & 0.505 & -0.395 \\
\hline GDPC85 & 0.106 & 0.945 & 1 & 0.954 & 0.291 & -0.241 & 0.275 & 0.409 & -0.306 \\
\hline Domestic Investment & 0.336 & 0.979 & 0.954 & 1 & 0.322 & -0.306 & 0.293 & 0.431 & -0.346 \\
\hline Military Participation & 0.412 & 0.4 & 0.291 & 0.322 & 1 & 0.134 & 0.265 & 0.455 & -0.413 \\
\hline Military Regime & -0.091 & -0.249 & -0.241 & -0.306 & 0.134 & 1 & -0.144 & -0.155 & 0.112 \\
\hline Primary Education & 0.278 & 0.342 & 0.275 & 0.293 & 0.265 & -0.144 & 1 & 0.728 & -0.462 \\
\hline Sencondary Education & 0.402 & 0.505 & 0.409 & 0.431 & 0.455 & -0.155 & 0.728 & 1 & -0.511 \\
\hline W.S. Education & -0.354 & -0.395 & -0.306 & -0.366 & -0.413 & 0.112 & -0.462 & -0.511 & 1 \\
\hline
\end{tabular}

$\sim$ Identifies a variable that has been residualized

${ }^{*}$ indicates t-Value $>1.5,{ }^{* *}$ Indicates t-value $>2.0,{ }^{* * *}$ Indicates $t$-value $>2.5$

Appendix D: Means, Standard Deviations and Correlations $(\mathrm{N}=59)$.

\begin{tabular}{|c|c|c|c|c|}
\hline Domestic Investment & Main & Semi & perip. & $\mathbf{R} 2$ \\
\hline Main effect as regressor & 0.677 & & & 0.784 \\
\hline Both Slope dummies as regressors & & 0.666 & 0.065 & 0.793 \\
\hline Semiperipheral slope dummy only as regressor & & 0.664 & & 0.789 \\
\hline Peripheral slope dummy only as regressor & & & -0.011 & 0.411 \\
\hline slope dummy correlation with the dep. Variable & & 0.728 & 0.244 & \\
\hline slope dummy intercorrelation & 0.017 & & & \\
\hline
\end{tabular}

Appendix E: Slope dummy Estimates \& Intercorrelations.

\begin{tabular}{|c|c|c|c|c|}
\hline Military Participation Ratio & Main & Semi & Perip. & $\mathbf{R 2}$ \\
\hline Main effect as regressor & 0.136 & & & 0.784 \\
\hline Both Slope dummies as regressors & & 0.199 & -0.094 & 0.795 \\
\hline Semiperipheral slope dummy only as regressor & & 0.204 & & 0.791 \\
\hline Peripheral slope dummy only as regressor & & & -0.106 & 0.776 \\
\hline slope dummy correlation with the dep. Variable & & 0.402 & -0.103 & \\
\hline slope dummy intercorrelation & -0.455 & & & \\
\hline
\end{tabular}

\begin{tabular}{|c|c|c|c|c|}
\hline Secondary Education Endrollment & Main & Semi & perip. & $\mathbf{R} 2$ \\
\hline Main effect as regressor & 0.207 & & & 0.784 \\
\hline Both Slope dummies as regressors & & 0.168 & 0.118 & 0.784 \\
\hline Semiperipheral slope dummy only as regressor & & 0.176 & & 0.779 \\
\hline Peripheral slope dummy only as regressor & & & 0.142 & 0.762 \\
\hline slope dummy correlation with the dep. Variable & & 0.402 & 0.018 & \\
\hline slope dummy intercorrelation & 0.072 & & & \\
\hline
\end{tabular}

\begin{tabular}{|c|c|c|c|c|}
\hline Primary Education Endrollment & Main & Semi & perip. & R2 \\
\hline Main effect as regressor & 0.222 & & & 0.784 \\
\hline Both Slope dummies as regressors & & 0.625 & 0.165 & 0.79 \\
\hline Semiperipheral slope dummy only as regressor & & 0.641 & & 0.785 \\
\hline Peripheral slope dummy only as regressor & & & 0.187 & 0.762 \\
\hline slope dummy correlation with the dep. Variable & & 0.26 & -0.115 & \\
\hline slope dummy intercorrelation & -0.822 & & & \\
\hline
\end{tabular}

The following tables displays the impact (Standardized Coefficient/beta weight)for each independent variable (except military 
Regime), as main effect (row 1), as two slope dummies (row 2 ), and as individual slope dummies entered separately (rows 3 \& 4). Bivariate correlations are displayed between each slope dummy and dependent variable (row 5) and between slope dummies themselves (row 6). Model estates used to generate these coefficients include all other independent variables as main effects (e.g. see table 1-3). Estimations also include a dummy variable coded 1 for membership in the semiperiphery (slope dummy main effect), in place of the W.S. position variable to specifically control for "position effects." The row specific R2 results from the saturated model estimation with the inclusion of the row-specific form of the regressor.

The world-system position dummy variables are multiplied by the respective capital component (e.g., military participation ratio) to produce two separate regressors that are termed "slope dummies." A slope-dummy variable is a form of interaction term created by multiplying a measurement variable (i.e., x1) by a dummy variable (i.e., $x 2$ ), which creates a new variable (i.e., $\mathrm{x} 1 \mathrm{x} 2$ ). This newly constructed variable $\mathrm{x} 1 \mathrm{x} 2$ has the values of $\mathrm{x} 1$ for all cases for which the dummy variable was " 1 " and zeros for all the remaining cases. Thus, two independent variables are created; the original measurement variable is split into two separate regressors, one representing the measurement variable in the semiperiphery and the other representing the measurement variable in the periphery (Foot Note 8). The slopedummy approach is described by Hamilton [112], and other world-system applications are offered in Burns, Kick and Davis [113], Jorgensen [114,115] and Shi [116].

A finding of "statistical significance" for a specific slope dummy simply indicates how (un)likely it would be to obtain a coefficient of that magnitude by chance alone. It does not indicate that the slopes for the semiperiphery and periphery for the given measurement variable (e.g., secondary education) are statistically different. Standardized regression coefficients associated with these slope dummy variables additionally indicate the relative performance of the measurement variable (e.g., secondary education) within that tier (i.e., semiperiphery or periphery) in explaining variation in the dependent variable while controlling for the other independent variables included in the model.

We believe this produces a far more appropriate wedding of theory and measurement since our theoretical framework emphasizes the coupling of two analytical domains rather than their independent effects. We are theoretically interested in effects of the couplings of capitals with structural location in the system, and our method more appropriately compares the effects of a specified capital in semiperipheral versus peripheral settings.

\section{Model estimation procedures}

Almost all published cross-national research in the area of national development has relied upon ordinary least squares (OLS) regression techniques and we use OLS herein. In another application heteroscedasticity and normality issues were examined and only a marginal difference emerged between OLS and minimum absolute deviation estimations for data comparable to those used here [15].

A first step for the OLS regressions was to examine the pattern of residuals for outlying cases (for in-depth discussion of effects of influential outliers, see [107]). Gabon, Oman, Singapore, Malta, Congo and Cameroon showed very high Cook's D values indicating their extreme influence on regression estimations. We decided that these 6 countries should be excluded from our analyses leaving our sample size at $\mathrm{N}=59$ (Foot Note 9).

The reasoning of Belsley et al. [117] prompted us to investigate the potential severity of multicollinearity. Initial analyses showed a number of estimation difficulties related to the relatively high intercorrelation between independent variables. The problems were those common to multicollinearity including: 1) covariations among the regression coefficients that resulted in coefficient sign changes as compared to initial bivariate correlations with the dependent variable, 2) dramatically increased standardized coefficient (beta weight) sizes relative to the initial bivariate correlations that included beta weights that exceeded unity, and 3) inflated standard errors that made rejection of the null hypothesis more difficult.

To address these problems, we dropped a redundant variable and adopted a hierarchical approach to orthogonalizing other affected variables (Foot Note 10). We removed the variance of the initial state of per capita gross domestic product from the domestic investment variable. We additionally removed the variance of primary education from secondary education given the temporal primacy of the former. With these adjustments we were able to dismiss multicollinearity as a pernicious force in our regressions.

\section{Results}

Regression results including standardized and unstandardized regression coefficients are presented in Tables 1, 2 and 3. The second column (column 2) in each table shows only "main effects" and the remaining columns (columns 3 and

\footnotetext{
${ }^{8}$ The couplings represent the relative performance of the specific measurement variable within a context where one tier is simultaneously compared to the other (semiperiphery versus periphery), and to all other estimates. Results demonstrating this are available from the authors upon request. Further information on slope dummy estimations and intercorrelations are provided for interested readers in
}

${ }^{9}$ We strongly encourage investigation of outlier effects in analyses involving cross-national samples such as ours.

${ }^{10}$ The correlations of the initial state of per capita product with domestic investments is .954 so that regression estimations with these two measures
included yield two beta weights greater than 1.0. Given these results it was necessary to establish semipartial correlations among these variables. We
note that our investigation of multicollinearity and usage of residualization is based on a great deal more information than examination of bivariate 
4) highlight the relative "coupling effects" discussed earlier. In order to minimize any multicollinearity attendant to entering multiple coupling terms with the same primitive components (in this case, world-system position) we highlight one coupling at a time, with the other variables in each column entered as main effects (Foot Note 11).

Table 1: Regression Results for change in Economic Development 1970-1985 (N=59) Economic Institution regressor in context.

\begin{tabular}{|c|c|c|c|}
\hline Variable & Correlation with Dep. Variable & Main Effect Beta (B) & $\begin{array}{c}\text { Relative Slopes for Domestic } \\
\text { Investment Beta (B) }\end{array}$ \\
\hline Domestic Investment & 0.78 & $0.75(2.84)^{* * *}$ & $0.75(2.89)^{* * *}$ \\
\hline semiperiphery & 0.77 & & $0.06(1.05)$ \\
\hline Peripehry & 0.16 & & $0.19(19.90)^{* *}$ \\
\hline Military Participation & 0.41 & $0.019(19.83)^{* *}$ & $0.10(5.30)$ \\
\hline Military Regime & -0.09 & $0.11(5.50)$ & $0.19(2.54)^{* *}$ \\
\hline Primary education & 0.28 & $0.17(4.88)^{* *}$ & $0.18(5.02)^{* *}$ \\
\hline Secondary Education & 0.3 & $-0.02(-0.01)$ & $-0.02(-0.01)$ \\
\hline GDPC70 & 0.11 & $0.02(4.43)$ & -0.01 \\
\hline W.S. Position & -0.35 & 0.75 & 0.76 \\
\hline R-Square & & 0.71 & 0.72 \\
\hline Adj. R-Square & & & \\
\hline
\end{tabular}

$\sim$ Identifies a variable that has been residualized.

${ }^{*}$ Indicates t-value $>1.5,{ }^{* *}$ Indicates t-value $>2.0,{ }^{* * *}$ Indicates t-value $>2.5$

Table 2: Regression Results for change in Economic Development 1970-1985 (N=59) Military Capital Regressors in Context.

\begin{tabular}{|c|c|c|c|c|}
\hline Variable & $\begin{array}{c}\text { Correlation with Dep. } \\
\text { Variable }\end{array}$ & Main Effect Beta (B) & $\begin{array}{c}\text { Relative Slopes for } \\
\text { Milatary Parcipation } \\
\text { Beta (B) }\end{array}$ & $\begin{array}{l}\text { Relative Slopes for } \\
\text { Milatary Regime Beta (B) }\end{array}$ \\
\hline Domestic Investment & 0.78 & $0.75(2.84)^{* * *}$ & $0.75(2.84)^{* * *}$ & $0.76(2.86)^{* * *}$ \\
\hline Military Parcipation & 0.41 & $0.19(19.83)$ & & $0.18(19.47)^{* *}$ \\
\hline SemiPeripehry & 0.45 & & $0.22(21.30)^{* *}$ & \\
\hline Peripehry & -0.22 & & $0.02(6.34)$ & \\
\hline Military Regime & -0.09 & $0.11(5.50)$ & $0.10(5.21)$ & \\
\hline SemiPeripehry & 0.08 & & & $0.11(6.00)$ \\
\hline Peripehry & -0.21 & & & $0.07(4.62)$ \\
\hline Primary Education & 0.28 & $0.17(2.39)^{* *}$ & $0.16(2.18)^{*}$ & $0.17(2.32)^{*}$ \\
\hline Secondary Education & 0.3 & $0.17(4.88)^{* *}$ & $0.16(4.65)^{*}$ & $0.17(4.88)^{* *}$ \\
\hline GDPC70 & 0.11 & $-0.02(-0.01)$ & $-0.02(-0.01)$ & $-0.02(-0.01)$ \\
\hline W.S. Position & -0.35 & $0.02(4.43)$ & $0.05(11.26)$ & $0.03(6.96)$ \\
\hline R-Square & & 0.75 & 0.75 & 0.75 \\
\hline Adj. Square & & 0.71 & 0.71 & 0.71 \\
\hline
\end{tabular}

$\sim$ Identifies a variable that has been residualized.

${ }^{*}$ Indicates t-value $>1.5,{ }^{* *}$ Indicates t-value $>2.0,{ }^{* * *}$ Indicates t-value $>2.5$

\footnotetext{
${ }^{11} \mathrm{As}$ a check on the robustness of our results we generated a range of other estimations based on a variety of regressor combinations. These included, among others: 1) the omission of all coupled regressors save one, serially, for each coupled variable; 2) the serial omission of the GDPC and world-system position regressors; 3) single-variable models for each regressor (and various combinations of two, three, and more regressors). The results we present in Tables 1-3 are a valid representation of both the direction of effects and their statistical significance or non-significance.
} 


\section{Agricultural Research \& Technology: Open Access Journal}

Table 3: Regression Results for Change in Economic Development 1970-1985 (N=59) Education capital Regressors in Context.

\begin{tabular}{|c|c|c|c|c|}
\hline Variable & $\begin{array}{c}\text { Correlation with Dep. } \\
\text { Variable }\end{array}$ & Main Effect Beta (B) & $\begin{array}{c}\text { Relative Slopes for } \\
\text { Primary Education Beta } \\
\text { (B) }\end{array}$ & $\begin{array}{c}\text { Relative Slopes for } \\
\text { Secondary Education } \\
\text { Beta (B) }\end{array}$ \\
\hline Domestic Investment & 0.78 & $0.75(2.84)^{* * *}$ & $0.75(2.84)^{* * *}$ & $0.75(2.84)^{* * *}$ \\
\hline Military Parcipation & 0.41 & $0.19(19.83)$ & $0.19(19.82)^{* *}$ & $0.19(19.81)^{* *}$ \\
\hline Militray Regime & -0.09 & $0.11(5.50)$ & $0.11(5.50)$ & $0.11(5.50)$ \\
\hline Primary Education & 0.28 & $0.17(2.39)^{* *}$ & & $0.17(2.32)^{*}$ \\
\hline SemiPeripehry & 0.32 & & $0.30(2.39)^{* *}$ & $0.11(6.00)$ \\
\hline Peripehry & -0.25 & $0.17(4.88)^{* *}$ & $0.20(2.42)$ & $0.17(4.90)^{*}$ \\
\hline Secondary Education & 0.3 & & & $0.15(4.91)^{*}$ \\
\hline SemiPeripehry & 0.28 & & $-0.02(-0.01)$ & $-0.02(-0.01)$ \\
\hline Peripehry & 0.13 & $-0.02(-0.01)$ & $0.05(4.10)$ & $0.02(4.18)$ \\
\hline GDPC70 & 0.11 & $0.02(4.43)$ & 0.75 & 0.75 \\
\hline W.S. Position & -0.35 & 0.75 & 0.71 & 0.71 \\
\hline R-Square & & 0.71 & & \\
\hline Adj. Square & & & & \\
\hline
\end{tabular}

$\sim$ dentifies a variable that has been residualized.

${ }^{*}$ Indicates t-value $>1.5,{ }^{* *}$ Indicates t-value $>2.0,{ }^{* * *}$ Indicates t-value $>2.5$

Immediately apparent in Table 1 is the large positive impact of domestic investment on economic growth when the sample is analyzed as a single pool of countries in the "main effects" column (column 2). It has been observed that "the more capital the more output," regardless of whether capital sources are internal or external to a nation $[27,118]$. Our results in column 3 question monolithic assertions of this type. While payoffs from domestic investment may be substantial for the semiperiphery, in relative terms they are trivial by comparison for the majority of the periphery. This is precisely the result anticipated by a capital coupling perspective informed by disarticulation arguments. While investment effects are not the central focus of this treatment, these processes result in the ever-widening GDPC gaps between core and periphery countries in particular (Foot Note 12).

The focal points of this treatment are the effects on economic growth of world-system couplings with social capitals. Table 2 results in the main effects column (column 2) show a positive effect of one measure of the military capital- the military participation ratio (MPR) - and in its generic (non dummysloped) form it persists in impact across the estimations presented (see Tables 1,3). MPR effects are consistent with

those arguments emphasizing that non-economic forces join economic dynamics in producing economic growth [63]. These MPR effects more specifically suggest that the military capital in developing nations in principle may train the labor force in literacy and numeracy, while instilling rationalized values related to discipline [24]. Military forces as well generate national improvements in infrastructure and communication networks [15]. Taken together these social forces can articulate with an increasingly complex division of labor and jointly foster economic growth.

However, it is only when military participation is coupled with semiperipheral position in the world system that its relative effects emerge (Table 2, column 3). By comparison, there are no relative economic growth payoffs of military participation for peripheral countries. We again emphasize this finding does not necessarily show that military participation has no favorable impact in the periphery. The findings suggest instead that the economic "payoff" to MPR is much greater for countries in the semiperiphery. This is due to the comparatively articulated character of economic and social capitals in the semiperiphery as they are coupled with comparatively greater nation-state power (Foot Note 13).

\footnotetext{
${ }^{12}$ We acknowledge Firebaugh's (1999) reticence to accept such omnibus assertions and admit the possibility that inequality trends in a few important cases may match the overall economic growth rate of the core. Such rates are of less interest to those world-system articulations that emphasize the mounting economic development chasms between core and periphery. That is, countries operating from a relatively large GDPC base and experiencing only modest growth rates will continue to outstrip others with the same or even higher rates of growth but a much lower base. Comparable observations can be made in comparisons of the semiperiphery and periphery.
}

${ }^{13}$ We concede that our methodological design does not permit us to specify and examine the specific impacts of the many MPR functions that may be central to economic growth. 
The absence of effects of military regimes (column 4) shows they are no more effective as producers of national economic growth than are their civilian counterparts (Foot Note 14). As theorized here and elsewhere, it is evident that the different components of domestic capitals can have variable effects on national outcomes even though their effects frequently are treated as monolithic. Our coupling perspective was silent on the differential effects of military regimes, and the comparative absence of negative regime effects for the periphery is unexpected in much of the literature. It is plausible that far more complex relationships characterize regime __ economic growth relationships in much of the developing world. An illustration of this is that civilian and military regimes may differ substantially in their styles of economic management with civilian regimes favoring urban consumers while military regimes favor industrial groups [80].

As a consequence defense-related expenditures may spur economic growth when military regimes are in power, but not when civilian regimes are. We freely admit these differences suggest more nuance is needed in theorizing the coupling approach to regime type and economic growth. Table 3 presents education effects on economic growth for semiperiphery and periphery nations. Payoffs are evident for both education measures in the main effects column (column 2), but are only evident in the semiperiphery when compared with the periphery (columns 3 and 4). Contributions for both levels of education come mainly through coupling nation-state power with relevant educational content that in the modern global system includes more advanced technical skills [10]. These effects for education are in line with prior findings as well as our coupling perspective, linking economic growth to the matching of world-system position with a more complex national division of labor based on nationalized production and human capital expansion.

The observed effect of both levels of education in the semiperiphery relative to the periphery countries suggests that the payoff to mass education comes primarily through its contributions to socialization as well as basic literacy and numeracy in advancing countries $[97,98]$. Unfortunately the capital coupling evidence provides peripheral countries little hope for comparative economic well-being and the beneficial social consequences that may spring from these same capitals in semiperipheral countries.

\section{Conclusion}

We emphasize the importance in both theoretical and methodological terms of the coupling between domains of analysis in studies of economic growth - in this case between the global system and domestic capitals. When they are taken together, our findings show that the economic growth effects of domestic investment are pronounced in the semiperiphery relative to the periphery. With respect to the social capitals that are the focal point of this paper we find that the contribution of both primary and secondary education in terms of promoting economic growth accrues to the semiperiphery relative to the periphery, which is consistent with our theorization and previous research.

It is worth noting also that primary education effects only exhibit statistical significance at all when secondary education is residualized for primary education. Favorable effects in the semiperiphery also are associated with military participation. This aspect of the military capital, but not military rule, complements or even is a partial functional alternative to other forms of education in generating economic growth. Future researchers would do well to take the human capital and infrastructural aspects of militarization as well as schooling seriously as they disentangle the sometimes different or competing effects of these components (Foot Note 15).

Meyer et al. [10] refer to a belief among elites that national "salvation lies in rationalized structures grounded in scientific and technical knowledge states, schools, firms, voluntary association, and the like." It is hardly surprising that noncore countries therefore attempt to model their capitals after the more developed countries [10,38]. As world-system and dependency theorists have long contended, this for the most part will not produce relative economic growth for poorer countries in the periphery of the world system (for examples of this in terms of investments in science, education and research, see $[119,120]$. Whole-scale modeling of Western ideology and capitals $[10,38]$ will be relatively ineffective when it is coupled to the disarticulated economies and capitals of the periphery, inasmuch as other key capital arrangements differ greatly for them as compared with other sectors of the world system.

While in many developing countries certain global-system and capital couplings may offer a rational or counter productive economic growth strategy, it is empirically uncertain to what degree these same coupling arrangements operate in developed countries. Recall that we focus on developing countries only in this treatment because the substantial global system, capital and economic growth differences between them are so often lost in the predominant emphasis on differences between rich and poorer countries only. However, an especially pertinent question at the moment is whether military participation engenders relatively favorable economic consequences in the core as it does in comparative terms for the semiperiphery [121]. A companion theoretical and empirical examination of such arrangements for the core of the global system therefore is suggested [106].

Also requiring clarity are the economic growth effects of couplings among domestic capitals themselves (e.g., education,

${ }^{14}$ In an earlier iteration of this paper, a reviewer wondered whether our coupling terms might only reflect world-system position and not the coupling as estimated. The absence of effects for both structural positions here, and comparable patterns elsewhere in the results, suggest this is not the case.

${ }^{151}$ t would be useful as well to consider empirically the possibility that the impact of the military will change as military outlays sponsor more technologically sophisticated components of the war machine with, arguably, less relevancy to the rest of the domestic economy outside the core of the world system. 
military, economy), which may vary considerably across the tiers of the modern global system. Coupling arguments should be extended to include the range of position-specific, subnational and capital relationships. Coupling arguments may also help to disentangle the sometimes different or competing effects of different components of national capitals.

There is mounting evidence that a perspective that incorporates treatment of national capital arrangements with global-system dynamics is needed in sociological theory $[118,122,123]$. The discourse around development is unnecessarily limited by strict adherence to "modernization," normative socialization, or human capital themes on the one hand, or world system/dependency themes, economic or cultural centered as they may be, on the other. A more accurate interpretation would be based on dynamics articulated by alternative schools-of-thought. We believe an capital coupling framework provides the sort of schema required for this discourse especially insofar as it links global power, national articulation, and the different components of social capitals to national development outcomes.

It is in line with this approach that we find global-system processes and national social capitals to be vital contributors to economic growth as postulated by a range of earlier economic and later cultural world-system/dependency and capital treatments. Clearly, national and capitals forces in conjunction determine national development.

\section{References}

1. Partes A (1976) On the Sociology of National Development: Theories and Issues. American Journal of Sociology 82(1): 52-85.

2. Sirid R (1993) World Military and Social Expenditures. (15 ${ }^{\text {th }}$ edn), World Priorities, Leesburg, USA.

3. World Bank (1999) The 1999 World Development Indicators CD-Rom. International Bank for Reconstruction and Development / World Bank Group. Washington DC, USA.

4. Firebaugh G (1999) Empirics of World Income Inequality. American Journal of Sociology 104(6): 1597-1630.

5. Immanuel W (1974) The Modern World System: Capitalist Agriculture and the Origins of the European World-Economy in the Sixteenth Century. Academic Press, New York, USA.

6. Sklair L (1999) Competing Conceptions of Globalization. Journal of World-Systems Research 2: 143-162.

7. Barro RJ (1997) Determinants of Economic Growth: A Cross-Country Empirical Study. The MIT Press, Cambridge, USA.

8. Harrison LE, SP Huntington (2000) Culture Matters: How Values Shape Human Progress. Basic Books, New York, USA.

9. Brinton MC (1998) The New Institutionalism In Sociology. Russell Sage Foundation, New york, USA, pp. 388.

10. Meyer JW, John B, Thomas GM, Francisco OR (1997) World Society and the Nation-State. American Journal of Sociology 103(1): 144-181.

11. Andreski S (1968) Military Organization and Society. Berkeley, University of California Press, CA, USA.

12. Benoit E (1973) Defense and Economic Growth in Developing Countries. Lexington Books, Massachusetts, USA 26(2): 271-280.
13. Weede E (1983) Military Participation Ratio, Human Capital Formation and Economic Growth: A Cross-National Analysis. Journal of Political and Military Sociology 11: 11-29.

14. Bullock B, G Firebaugh (1990) Guns and Butter? The Effect of Militarization on Economic and Social Development in the Third World. Journal of Political and Military Sociology 18: 231-266.

15. Kick EL, BL Davis, Kiefer DM, Burns TJ (1998) A Cross-National Analysis of Militarization and Well-Being Relationships in Developing Countries. Social Science Research 27: 351-370.

16. Inkeles Alex, David Smith (1974) Becoming Modern: Individual Change in Six Developing Countries. Cambridge, Harvard University Press, USA

17. Almond GA, S Verba (1963) The Civic Culture: Political Attitudes and Democracy in Five Nations. Newbury Park, Sage, USA.

18. Hage J, Maurice G (1990) Education and Economic Growth in Germany. Research in Sociology of Education and Socialization 9: 25-53.

19. Hage J, M Garnier (1988) The Active State, Investment in Human Capital, and Economic Growth: France 1825-1975. American Sociological Review 53(6): 824-837.

20. Barnhouse WP, R Rubinson (1983) Educational Expansion and Economic Output in the United States, 1890-1969: A Production Function Analysis. American Sociological Review 48(4): 480-493.

21. A Comte (1842/1854) The Positive Philosophy of Auguste Comte. D Appleton, USA.

22. Spencer H (1887) The Factors of Organic Evolution. London: Williams and Norgate.

23. Durkheim E (1893/1984) The Division of Labor in Society. Free Press, New York, USA, pp. 236-220.

24. Weber M (1921/1968) Economy and Society. Totowa, Bedminster NJ, USA, pp. 1155

25. Parsons T (1966) The Social System. Free Press, New York, USA.

26. Eisenstadt, SN (1974) Studies of Modernization and Sociological Theory. History and Theory 13(3): 225-252.

27. Rostow, WW (1962) The Stages of Economic Growth: A Non-Communist Manifesto. Cambridge, Cambridge University Press, MA, USA

28. Raul, P (1962) Inter-Related Conditions for Latin American Development. Ensayos 1: 52-60.

29. Frank A. (1966) The Development of Underdevelopment. Monthly Review 18: 17-31.

30. Cardoso, FH (1970) Structural and Institutional Impediments to Development. Revista Mexicana de Sociologia 32(6): pp. 1461-1482.

31. Cardoso FH, Enzo F (1979) Dependency and Development in Latin America. Berkeley, University of California Press, CA, USA.

32. Evans P (1979) Dependent Development: The Alliance of Multinational, State, and Local Capital in Brazil. Princeton, Princeton University Press, USA 87(6): 1398-1400.

33. Meyer JW, M. Hannan, R. Rubinson, Richard R, George MT (1979) National Economic Development, 1950-1970: Social and Political Factors. In: John WM, Michael TH (Eds.), National Development and the World System: Educational, Economic, and Political Change 19501970. University of Chicago Press, Chicago, pp. 85-116.

34. Armer Michael, Insook Jeong, Richard Rubinson (1989) The Contributions of Schooling to Economic Growth in East Asia: Japan, Korea, and Taiwan. American Sociological Association Proceedings Paper, USA.

35. Delacroix J, C. Ragin (1981) Structural Blockage: A Cross-National Study of Economic Dependency, State Efficacy, and Underdevelopment. American Journal of Sociology 86(6): 1311-1347. 
36. Snyder D, E.L. Kick (1979) Structural Position in the World System and Economic Growth. 1955-1970: A Multiple-Network Analysis of Transnational Interactions. American Journal of Sociology 84(5): 1096-1126.

37. Chase-Dunn C (1989) Global Formation: Structures of the Global Economy. Cambridge, Basil Blackwell, MA, USA.

38. John B, Thomas GM (1997) Constructing World Culture: International Non-Governmental Organizations Since 1875. Stanford: Stanford University Press, USA 62(2): 171-190.

39. Ramirez F, J. Boli (1987) The Political Construction of Mass Schooling: European Origins and Worldwide Institutionalization. Sociology of Education 60(1): 2-17.

40. Biggart NW, Guillen MF (1999) Developing Difference: Social Organization and the Rise of the Auto Industries of South Korea, Taiwan, Spain, and Argentina. American Sociological Review 64(5): 722-747.

41. Emerson RM (1962) Power-Dependence Relations. American Sociological Review 27(1): 31-41.

42. Emerson RM (1981) Social Exchange Theory. In: Rosenberg M, Turner R (Eds.), Social Psychology: Sociological Perspectives Basic Books, New York, USA, pp. 30-65.

43. Homans G (1961) Social Behavior. Harcourt, Brace and World, New York, USA.

44. Blau Peter (1964) Exchange and Power in Social Life. John Wiley, New York, USA.

45. R Emerson, M. Gilmore, T. Yamagishi (1983) The Distribution of Power in Exchange. Theory and Experimental Results. American Journal of Sociology 89(2): 275-305.

46. Harriet F (1998) Form and Substance in the Analysis of the World Economy. In: Wellman B, Berkowitz SD (Eds.), Social Structures: A Network Approach, Cambridge University Press, New York, USA, pp. 304-325.

47. Chirot D (1977) Social Change in the Twentieth Century. Harcourt, Brace and Jovanovich, New York, USA.

48. Chase-Dunn C, Richard R (1977) Toward a Structural Perspective on the World System. Politics and Society 7: 453-476.

49. Giovanni A, J Drangel (1986) The Stratification of the World-Economy: An Exploration of the Semi-Peripheral Zone. Review 10(1): 9-74.

50. Szymanski, A (1981) The Logic of Imperialism. Praeger, New York, USA

51. Galtung, G. (1971) A Structural Theory of Imperialism. Journal of Peace Research 8: 81-117.

52. Amin Samir (1974) Accumulation on a World Scale. New York: Monthly Review Press, USA, pp. 648.

53. Amin Samir (1976) Unequal Development. Monthly Review Press, New York, USA.

54. Breedlove WL, Armer J.M. (1997) Dependency, Techno-Economic Heritage, Disarticulation, and Social Development in Less Developed Nations. Sociological Perspectives 40(4): 661-680.

55. Hirschman AO (1958) The Strategy of Economic Development. New Haven, Yale University Press, CT, USA.

56. Arthur WB (1994) Increasing Returns and Path Dependence in the Economy. Ann Arbor, University of Michigan Press, USA, pp. 224.

57. Arthur WB (1999) Complexity and the Economy. Science 284: 107-109.

58. Krugman P (1995) Development, Geography, and Economic Theory. MIT Press, Cambridge, USA.
59. Sachs, J. (2000) Notes on a New Sociology of Economic Development In: Harrison L, Huntington SP (Eds.), Culture Matters: How Values Shape Human Progress. Basic Books, New York, USA, pp. 29-43.

60. Sunkel, O. C (1973) Transnational Capitalism and National Disintegration in Latin America. Social and Economic Studies 22(1): 132-176.

61. North, D. (1998) Economic Performance Through Time. In: Brinton M, Nee V (Eds.), The New Institutionalism In Sociology, Russell Sage Foundation. New York, USA, pp. 247-257.

62. Levy, M. (1952) The Structure of Society. Princeton, Princeton University Press, NJ, USA.

63. McClelland DG (1961) The Achieving Society. Free Press, New York, USA.

64. Campbell JL, Pedersen, O (eds) (2001) The Rise of Neoliberalism and Institutional Analysis. Princeton, Princeton University Press, NJ, USA.

65. Michael P (2000) Notes on a New Sociology of Economic Development. In: Harrison L, Huntington SP (Eds.), Culture Matters: How Values Shape Human Progress, Basic Books, New York, USA, pp. 14-28.

66. Stace L (2000) Promoting Progressive Cultural Change. In: Harrison L, Huntington SP (Eds.), Culture Matters: How Values Shape Human Progress, Basic Books, New York, pp. 282-295.

67. Inglehart, R. (2000) Social Capital. In: Harrison L, Huntington SP (Eds.), Culture Matters: How Values Shape Human Progress. Basic Books, USA, pp. 80-97.

68. Grondona, M. (2000) Culture and the Behavior of Elites in Latin America. In: Harrison L, Huntington SP (Eds.), Culture Matters: How Values Shape Human Progress. Basic Books, New York, USA.

69. Hannan MT and J. Freeman (1987) The Ecology of Organizational Founding: American Labor Unions, 1836-1985. American Journal of Sociology 92(4): 910-943.

70. DiMassio PJ, Powell WW (1983) The Iron Cage Revisited: Institutionalism Isomorphism and Collective Rationality in Organizational Fields. American Sociological Review 48(2): 147-160.

71. Dobbin, Frank (1994) Forging Industrial Policy. Cambridge University Press, USA.

72. Eide, A. (1976) Arms Transfer and Third World Militarization. Bulletin of Peace Proposals 8: 99-102.

73. Senghaas, D. (1977) Militarism Dynamics in the Contemporary Context of Peripheral Capitalism. Bulletin of Peace Proposals 8: 103-109.

74. McKinlay RD, Mughan A (1984) Aid and Arms to the Third World. St. Martins Press, New York, USA, pp. 251-258.

75. Robert EL (1989) The Economic Impact of Rent Seeking and Military Expenditures: A Comparison of Third World Military and Civilian Regimes. The American Journal of Economics and Sociology 48(1): 1129.

76. Pye, L. (1962) Armies in the Process of Political Modernization. In: John JJ (Edt.), The Role of the Military in Underdeveloped Countries, Greenwood Press, Princeton, USA, pp. 69-89.

77. Janowitz, M. (1964) The Military in the Political Development of New Nations. University of Chicago Press, USA.

78. Weede E (1986) Rent Seeking, Military Participation and Economic Performance in LDCs. Journal of Conflict Resolution 30(2): 291-314.

79. Kick EL, Sharda, B.D (1986) Third World Militarization and Development. Journal of Developing Societies 2: 49-67.

80.Sen, G. (1984) The Military Origins of Industrialization and International Trade Rivalry. Frances Pinter Pubs. LTD, USA. 
81. Bunbongkarn S (1991) The Thai Military and Its Role in Society in the 1990s. In: Selochan V(Ed.), The Military, the State, and Development in Asia and the Pacific. Boulder, Westview, USA, pp. 67-81.

82. Newman S (1978) Security, Military Expenditures and Socioeconomic Development: Reflections on Iran. ORBIS 22: 569-594.

83. Sanday, J. (1991) The Politicization of Military Professionalism in Fiji. In: Selochan v (Edt.), The Military, The State, and Development in Asia and the Pacific, Boulder, Westview, USA, pp. 239-270.

84. Looney RE (1990) The Policy Relevance of Recent Research on the Economics of Third World Military Expenditures. Journal of Social, Political, and Economic Studies 15(2): 213-223.

85. Babin, Nehama (1990) Military Expenditures and Education: Allies or Adversaries in Third World Development. Journal of Political and Military Sociology 18(2): 267-283.

86. Goertzel, T. (1986) Anti-Militarism and Democracy in Central America: Comparative Analysis of an Exceptional Case. International Sociological Association Proceedings Paper.

87. Jeong, I and M. Armer (1994) State, Class, and Expansion of Education in South Korea: A General Model. Comparative Education Review 38(4): 531-545.

88. Robert L, Verry D (1996) Growth and Income Distribution in Malaysia. International Labour Review 135: 553-575.

89. Benefit Aaron (1992) Educational Expansion and Economic Growth in the Modern World, 1913-1985. In: Bruce Fuller, Richard Rubinson (Eds.), The Political Construction of Education: The State, School Expansion, and Economic Change. Praeger, USA, pp. 117-134.

90. Killick T (1994) East Asian Miracles and Development Ideology. Development Policy Review 12: 69-79.

91. Brock-Utne, Birgit. (1995) Cultural Conditionality and Aid to Education in East Africa. International Review of Education 41(3/4): 177-197.

92. Mazrui, A. (1997) The World Bank, the Language Question and the Future of African Education. Race and Class 38: 35-48.

93. Psacharopoulos, George, Velez E, Panagides A, Yang H (1996) Returns to Education During Economic Boom and Recession: Mexico 1984 1989 and 1992. Education Economics 4: 219-230.

94. Kick EL (1987) World-System Structure, National Development, and the Prospects for a Socialist World Order. In: Boswell T, Bergesen A (Eds.), America's Changing Role in the World System. Praeger, USA, pp. 127-155.

95. Terry B, Dixon WJ (1990) Dependency and Rebellion: A CrossNational Analysis. American Sociological Review 55: 540-559.

96. Bruce L, Smith DA (1988) Urban Bias, Dependence, and Economic Stagnation in Noncore Nations. American Sociological Review 53(3): 454-463.

97. Kick EL, Byron LD (2001) World-System Structure and Change: An Analysis of Global Networks and Economic Growth Across Two Time Periods. American Behavioral Scientist 44: 1561-1578.

98. Alderson Arthur (1999) Explaining Deindustrialization: Globalization, Failures, or Success? American Sociological Review 64(5): 701-721.

99. Bollen K, Robert WJ (1985) Regression Diagnostics: An Expository Treatment of Outliers and Influential Cases. Sociological Methods and Research 13: 510-12.

100. US Arms, Arms Control and Disarmament Agency (1989) World Military Expenditures and Arms Transfers. U.S. Arms Control and Disarmament Agency. Washington DC, USA.

101. Hamilton LC (1992) Regression With Graphics: A Second Course in Applied Statistics. Pacific Grove, Brooks/Cole Publishing Company, CA, USA.
102. Burns TJ, Edward LK, Davis B. (2003) Theorizing and Rethinking Linkages between the Natural Environment and the Modern WorldSystem: Deforestation in the Late $20^{\text {th }}$ Century. Journal of WorldSystems Research 9: 357-392.

103. Jorgenson, A (2003) Consumption and Environmental Degradation: A Cross-National Analysis of the Ecological Footprint. Social Problems 50(3): 374-394.

104. Jorgenson, A (2004) Uneven Processes and Environmental Degradation in the World-Economy. Human Ecology Review 11: 103117.

105. Yehouda S, Kamens D (1991) The Costs of Institutional Isomorphism in Non-Western Countries. Social Studies of Science 21: 427-545.

106. Belsley DA, Kuh E, Welsch RE (1980) Regression Diagnostics: Identifying Influential Data and Sources of Collinearity. Wiley, New York, USA.

107. Firebaugh G (1992) Growth Effects of Foreign and Domestic Investment. American Journal of Sociology 98(1): 105-130.

108. Schofer E, Ramirez FO, Meyer JW (1997) The Effect of Science on National Economic Development, 1970-1990. Paper presented at the annual meeting of the American Sociological Association, Toronto, Canada 65(6): 866-887.

109. Alderson AS, Nielsen F (1999) Income Inequality, Development and Dependence: A Reconsideration. American Sociological Review 64(4): 606-631.

110. Firebaugh G, Beck FD (1994) Does Economic Growth Benefit the Masses? American Sociological Review 59(5): 631-653.

111. Indra DS, Oneal JR (1999) Boon or Bane? Reassessing the Productivity of Foreign Direct Investment. American Sociological Review 64(5): 766-782.

112. Arthur WB (1994) Increasing Returns and Path Dependence in the Economy. Ann Arbor, University of Michigan Press, USA, pp. 224.

113. Davis, B. Kick EL, Kiefer D (1989) The World-System, Militarization, and National Development. In: Robert K Schaeffer (Edt.), War in the World-System, Greenwood, New York, USA.

114. Giddens Anthony (1985) The Nation-State and Violence. Berkeley, University of California Press, CA, USA.

115. Meyer JW, John B, Thomas GM, Francisco OR (1997) World Society and the Nation-State. American Journal of Sociology 103(1): 144-181.

116. Meyer JW, Rubinson R, Ramirez FO, Boli-Bennett J (1977) The World Educational Evolution, 1950-1970. Sociology of Education. 50(4): pp. 242-258.

117. Robinson WI (2004) A Theory of Global Capitalism: Production, Class and State in a Transnational World. Cambridge University Press, Cambridge, USA 20(2): 81-86.

118. Sivard, R. (1987) World Military and Social Expenditures, (12 ${ }^{\text {th }}$ edn), World Priorities, Leesburg, USA.

119. Morris, A.S. (1997) The Little Asian Tigers: Identities, Differences and Globalization. Oxford Studies in Comparative Education 7: 203-223.

120. United Nations (1993) Human Development Report 1993. Oxford University Press, New York, USA.

121. Mann, M. (1988) States, War and Capitalism. Oxford, Blackwell, USA.

122. Meyer JW, Joanne N, Conrad WS (1993) The Expansion of Mass Education in Botswana: Local and World Society Perspectives. Comparative Education Review 37(4): 454-475. 
This work is licensed under Creative Commons Attribution 4.0 License DOI: $10.19080 /$ ARTOAJ.2017.11.5557822

\section{Your next submission with Juniper Publishers} will reach you the below assets

- Quality Editorial service

- Swift Peer Review

- Reprints availability

- E-prints Service

- Manuscript Podcast for convenient understanding

- Global attainment for your research

- Manuscript accessibility in different formats

( Pdf, E-pub, Full Text, Audio)

- Unceasing customer service

Track the below URL for one-step submission https://juniperpublishers.com/online-submission.php 